\title{
Effects of Occupational Exposure to Wood Smoke in Tandoor Occupants
}

\author{
Ghulam Nabi \\ Student, Department of Zoology, University of Malakand Chakdara \\ Dir (L), Khyber Pakhtunkhwa, Pakistan \\ E-mail: ghulamnabi751@ rocketmail.com \\ Jeena Urooj \\ Student, Department of Zoology, University of Malakand Chakdara \\ Dir (L), Khyber Pakhtunkhwa, Pakistan \\ E-mail:jeenaurooj@yahoo.com
}

\begin{abstract}
Ayaz Ali Khan (Corresponding Author)
Assistant Professor, Department of Biotechnology, University of Malakand Chakdara

Dir (L), Khyber Pakhtunkhwa, Pakistan

E-mail: lalatejan@gmail.com
\end{abstract}

\begin{abstract}
Ghazala Yasmin Zamani
Lecturer, Department of Biotechnology, Bacha Khan Unviersity Charsada

Khyber Pakhtunkhwa,Pakistan

E-mail: ghazala.zamani@yahoo.com
\end{abstract}

Mussarat Wahid

M. Phil, Department of Bio Sciences

Comsats Institute of Information Technology, Islamabad

E-mail: mussaratwahid@yahoo.com 
Saleem-Ur-Rahman

Student, Department of Biotechnology, University of Malakand Chakdara

Dir (L), Khyber Pakhtunkhwa, Pakistan

E-mail: saleemurrrahman20@gmail.com

Received: August 3, 2013 Accepted: August 17, 2013

doi:10.5296/jbls.v5i2.4079 URL: http://dx.doi.org/10.5296/jbls.v5i2.4079

\begin{abstract}
Exposure to wood smoke leads to mucosal irritation and physiological and neurological abnormalities in human.Blood samples along with histories were taken from 100(50Tandoor occupants and 50 controls) male individualsliving in the same locality. SYSMIX KX-21 (Japan) and Shimadzu Double Beam Spectrophotometer 1700 Pharma (Japan) were used for blood profiling and serum biochemistry. In workers, blood cholesterol was $131 \pm 4.8 \mathrm{mg} / \mathrm{dl}$, triglyceride was $125 \pm 10 \mathrm{mg} / \mathrm{dl}$, and serum glutamate pyruvate transaminase level was $68 \pm 2.4 \mathrm{IU} / \mathrm{L}$ and glucose level was $113 \pm 2.1 \mathrm{mg} / \mathrm{dl}$. The total red blood cell count was $5.6 \pm 0.035 \mathrm{mill} / \mathrm{cmm}$, hemoglobin level was $15 \pm 0.054 \mathrm{mg} / \mathrm{dl}$, hematocrit value was $49 \pm 0.22 \mathrm{mg} / \mathrm{dl}$, mean corpuscular volume was $86 \pm 0.22 \mathrm{fl}$, mean corpuscular hemoglobin was $31 \pm 0.12 \mathrm{pg}$, mean corpuscular hemoglobin concentration was $35 \pm 0.12 \mathrm{gm} / \mathrm{dl}$, neutrophils were $77 \pm 0.50 \%$, lymphocytes were $45 \pm 1.0 \%$, eosinophilswere $6.0 \pm 0.14 \%$, monocytes were $7.7 \pm 0.19 \%$, total leukocyte count were $11014 \pm 115 / \mathrm{cmm}$, and platelets were $235864 \pm 5491 / \mathrm{cmm}$. In control group the blood cholesterol, triglyceride, serum glutamate pyruvate transaminase and glucose level was $111 \pm 2.4 \mathrm{mg} / \mathrm{dl}, 97 \pm 1.5 \mathrm{mg} / \mathrm{dl}, 28 \pm 1.1 \mathrm{IU} / \mathrm{L}$ and $101 \pm 1.2 \mathrm{mg} / \mathrm{dl}$ respectively, while thetotal red blood cell count, hemoglobin level, hematocrit value, mean corpuscular volume, mean corpuscular hemoglobin, mean corpuscular hemoglobinconcentration, neutrophils, lymphocytes, eosinophils, monocytes, leukocyte, and platelets were4.3 \pm $0.027 \mathrm{mil} / \mathrm{cmm}, 12 \pm 0.064 \mathrm{mg} / \mathrm{dl}, 38 \pm 0.11 \mathrm{mg} / \mathrm{dl}, 75 \pm 0.30 \mathrm{fl}, 25 \pm 0.37 \mathrm{pg}, 31 \pm 0.11 \mathrm{gm} / \mathrm{dl}, 56$ $\pm 0.82 \%, 34 \pm 1.0,3.1 \pm 0.20 \%, 4.2 \pm 0.12 \%, 6573 \pm 125$, and $169162 \pm 2454 / \mathrm{cmm}$ respectively.The levels in both groups were statistically compared using $t$ test and the palue was determined.The results showed that there was significant increase in blood biochemical parameters as well as in complete blood count in workers as compared to control and are therefore at more risk to heart, lungs and blood diseases.
\end{abstract}

Keywords: Tandoor, Wood smoke, Hematology, Blood biochemical parameters

\title{
1. Introduction
}

A Tandoor is a cylindrical clay oven used for cooking and baking in many countries like Pakistan, India, Turkey, Iran, Afghanistan, Burma and Bangladesh (Steven 2011). Burning wood used in Tandoor emits toxic particles in air that contains carbon monoxide $(\mathrm{CO})$, 


\section{Mll Macrothink}

Journal of Biology and Life Science ISSN 2157-6076 2014, Vol. 5, No. 2

Nitrogen Oxides (NOx), Volatile Organic Compounds (VOCs), Dioxin, and Inhalable Particulate Matter (PM) (Minnesota Pollution Control Agency 2012) due to which cardiovascular, coronary artery diseases, cerebro-vascularsdiseases and venous thrombo-embolism occurred in people that are exposed (Fraanchini 2011). According to the recent studies, each year, ten of thousands of premature cardiovascular death occurs, the mechanisms of which remain uncertain (Schwartz 2001). Long time exposure also leads to death from coronary heart diseases (Nemmar et al 2006). Air pollutant when inhale, affects blood pressure (Simkhovich et al 2008). The improved stove intervention was associated with $3.7 \mathrm{~mm} \mathrm{Hg}$ lower systolic blood pressure (SBP) after adjusting for age, body mass index, smoking, second hand tobacco smoke, apparent temperature, season, day of week and time of day (Mccracken 2010). Exposure to wood smoke leads to irritation of the mucous as well as physiological and neurological effects in human (Riddervold et al 2011) and they causes reduced lung function in rural Africans (Fullerton et al2011). The particulate matter in kitchen is associated with chronic obstructive pulmonary diseases and lung cancer in women (Perez et al 2010).In Pakistan 94\% of households in rural areas and 58\% in urban areas depend on biomass fuels (wood, dung, and agricultural waste) due to incomplete combustion of the biomass fuels, the resulting smoke contains a range of health-worseningsubstances that, at varying concentrations, can causea serious threat to human health. Indoor air pollution accounts for 28,000 deaths a year and 40 million cases of acute respiratory illness. It places a significant economic burden on Pakistan with an annual cost of $1 \%$ of GDP (Colbeck et al 2010). The present study was conducted to study the general health status of Tandoor occupants exposed to wood smoke and its effects on blood biochemical parameters of the occupants and hematological parameters.

\section{Materials and Methods}

\section{Questionnaire}

For the present study,a standard questionnaire was formulated for collecting specific information from Tandoor occupants and control group regarding their age, marital status, type of fuel, addiction, health status, exposure time to smoke and other particulars. The study was approved by the ethical board of University of Malakand.

\section{Data collection}

The study was approved by the ethical board of University of Malakand. During sampling, 100 (50 workers irrespective to their age and working hours in Tandoor and 50 controls) maleindividuals were selected. A written consent was signed from all individuals before taking interviews. The blood samples from Tandoor occupants and healthy individuals (Control) were collected from (Chakdara, Gulabad and Tazagram), at Dir (Lower), Khyber Pakhtunkhwa, Pakistan, that was made in October, 2011 till April,2012.

\section{Blood sampling from Tandoor occupants}

Blood sample $(5 \mathrm{ml})$ was taken from the workers and $3 \mathrm{ml}$ of the blood was transferred to heparinized test tube for blood profiling. Blood sample $(2 \mathrm{ml})$ was transferred to other test tube having no any anticoagulant for isolation of serum that was used for biochemical tests. The 
samples were immediately analyzed and those which were kept pending, transferred to $-20^{\circ} \mathrm{C}$ refrigerator for storage.

\section{Blood sampling from control}

The people living all around the area near Tandoor shops were kept as control. A total of 50 people were randomly selected from those areas. Same procedure was adopted for collection of blood and isolation of serum as that of workers.

\section{Serum isolation}

Test tubes were kept in slant position. Serum oozed out, and transferred to the other sterilized test tubes. Serum was used for analysis of different chemicals (Cholesterol, Glucose, Serum Glutamate Pyruvate Transaminase (SGPT) and Triglycerides (TG) in blood.

\section{Equipment used}

SYSMIX KX-21(Japan) was used for the determination of complete blood profile and Shimadzu Double Beam Spectrophotometer 1700 Pharma (Japan) was used for blood biochemistry.

\section{Statistical analysis}

The data obtained was statistically analyzed. Mean, standard deviation, column statistics/row statistics and $t$ test were used for the comparison of both the groups (control and workers) were performed for each parameter using Graphpad Prism, Demo version 05 (www.graphpad.com).

\section{Results and Discussions}

The present study is based on studying the effects of Tandoor smoke on health status of the occupants. The adverse effects of the toxicants in wood smoke are a common phenomenon in all the developing countries. The awareness about this problem is lacking in Pakistan, particularly in Khyber Pakhtunkhwa. To collect the specific information from workers as well as control, a questionnaire was formulated regarding their age and health status. The information collected was summarized (Table.1).The results of biochemical parameters such as Cholesterol, Triglycerides, Glucose, SGPT and complete blood profile of both workers and control are listed(Table.2).

\section{History of workers and control}

In the present study, both workers and control group were divided into different age groups. Control group was mostly normal (Table. 1) while workers, who were frequently exposed to wood smoke, had hypertension, lungs abnormalities, chest pain and physical weakness (Table. 1). These problems were correlated with age and thus more prominent in elder people than young ones.Kodgule and Salvi 2012 stated that increased mortality and morbidity is associated with exposure to biomass smoke. Minnesota Pollution Control Agency2012 have also given same report that irritation of eyes, lungs, throat and sinuses, increases severity of existing lung diseases such as asthma, emphysema, pneumonia and bronchitis, and chronic obstructive lung disease and chronic bronchitis are associated with short term and long term exposure to wood smoke.Kunzliet al2006studied exposure to heavy smoke of wildfires and concluded thatthe nose, eyes, and throat irritations, cough, bronchitis, cold, wheezing, asthma attacks were associated with 
individually reported exposure differences within communities.Rajpandey 1984 found that wood smoke inhalation causes chronic bronchitis in adults; chronic interstitial pneumonitis andfibrosis (Ramage et al 1988), interstitial lung disease, pulmonary arterial hypertension (Sandoval et al 1993), and altered pulmonary immune defense mechanisms (Demarest et al 1979 and Ramage et al 1988).

Table 1. History of workers and control

\begin{tabular}{|c|c|c|c|c|c|c|c|c|c|}
\hline $\begin{array}{c}\text { Age } \\
\text { Group } \\
\text { (Years) }\end{array}$ & $\begin{array}{c}\text { No. of } \\
\text { Workers }\end{array}$ & $\begin{array}{c}\text { Economic } \\
\text { status }\end{array}$ & $\begin{array}{c}\text { Marital } \\
\text { Status }\end{array}$ & $\begin{array}{c}\text { Type } \\
\text { of } \\
\text { Fuel } \\
\text { used }\end{array}$ & $\begin{array}{c}\text { Exposure } \\
\text { Time } \\
\text { (Months) }\end{array}$ & $\begin{array}{c}\text { Addiction } \\
(\%)\end{array}$ & $\begin{array}{c}\text { Use } \\
\text { of } \\
\text { Mask }\end{array}$ & $\begin{array}{l}\text { Health } \\
\text { status } \\
\text { (Before } \\
\text { Job) }(\%)\end{array}$ & $\begin{array}{c}\text { Health status } \\
\text { (After Job) } \\
(\%)\end{array}$ \\
\hline $\begin{array}{c}\text { Workers } \\
18-25\end{array}$ & 20 & Poor & $\begin{array}{l}15 \\
\text { Unmarried } \\
05 \text { married }\end{array}$ & Wood & $72-90$ & $\begin{array}{l}09 \text { Snuff } \\
00 \\
\text { Cigarettes }\end{array}$ & No & $\begin{array}{c}\text { No } \\
\text { Specific }\end{array}$ & $\begin{array}{l}06 \text { RTI*, } \\
03 \text { Rhinitis, } \\
08 \quad \text { Eye } \\
\text { discharge, } \\
02 \text { Hypertension }\end{array}$ \\
\hline $26-33$ & 15 & Poor & $\begin{array}{l}\text { 06Unmarried } \\
09 \text { married }\end{array}$ & Wood & $120-140$ & $\begin{array}{l}10 \quad \text { Snuff } \\
\text { 01Cigarettes }\end{array}$ & No & $\begin{array}{l}02 \text { GIT* } \\
\text { disorders. }\end{array}$ & $\begin{array}{l}05 \text { RTI*, }^{*} \\
03 \text { Rhinitis, } \\
02 \quad \text { Eye } \\
\text { discharge, } \\
\text { 05 Hypertension }\end{array}$ \\
\hline $34-41$ & 10 & Poor & $\begin{array}{l}\text { 02Unmarried } \\
08 \text { married }\end{array}$ & Wood & $110-120$ & $\begin{array}{l}10 \text { Snuff } \\
00 \\
\text { Cigarettes }\end{array}$ & No & $\begin{array}{c}01 \\
\text { G.B.A*. }\end{array}$ & $\begin{array}{l}10 \text { RTI*, }^{*} \\
05 \text { Rhinitis, } \\
05 \quad \text { Eye } \\
\text { discharge } \\
00 \text { Hypertension }\end{array}$ \\
\hline $42-49$ & 5 & Poor & $\begin{array}{c}00 \\
\text { unmarried } \\
\text { 05 Married }\end{array}$ & Wood & $140-160$ & $\begin{array}{l}07 \text { Snuff } \\
02 \\
\text { Cigarettes }\end{array}$ & No & $\begin{array}{c}05 \\
\text { Physical } \\
\text { weakness }\end{array}$ & $\begin{array}{l}\text { 03RTI*, } \\
\text { 03Rhinitis, } \\
02 \text { Eye } \\
\text { discharge, } \\
\text { 01Hypertension, } \\
\text { 02 Lumbago, } \\
\text { 04 Chest pain }\end{array}$ \\
\hline $\begin{array}{c}\text { Control } \\
18-25\end{array}$ & 22 & Poor & $\begin{array}{l}17 \\
\text { Unmarried } \\
05 \text { Married }\end{array}$ & No & 00 & $\begin{array}{l}03 \text { Snuff } \\
\text { 00Cigarettes }\end{array}$ & No & 00 & 00 \\
\hline $26-33$ & 13 & Poor & $\begin{array}{l}01 \\
\text { Unmarried } \\
12 \text { Married }\end{array}$ & No & 00 & $\begin{array}{l}06 \text { Snuff } \\
00 \\
\text { Cigarettes }\end{array}$ & No & 00 & 00 \\
\hline $34-41$ & 8 & Poor & $\begin{array}{l}00 \\
\text { Unmarried } \\
08 \text { Married }\end{array}$ & No & 00 & $\begin{array}{l}03 \text { Snuff } \\
00 \\
\text { Cigarettes }\end{array}$ & No & 00 & 00 \\
\hline $42-49$ & 7 & Poor & $\begin{array}{l}00 \\
\text { Unmarried }\end{array}$ & No & 00 & $\begin{array}{l}00 \text { Snuff } \\
00\end{array}$ & No & 00 & 00 \\
\hline
\end{tabular}


07 Married

Cigarettes

*RTI: Respiratory Tract Infection, *GIT: Gastro Intestinal Tract, *GBA: General Body Aches,

\section{Blood Cholesterol}

The mean and standard deviation of workers was high $(131 \pm 4.8 \mathrm{mg} / \mathrm{dl})$ as compared to control $(111 \pm 2.4 \mathrm{mg} / \mathrm{dl})$ for cholesterol (Table2).Particulate matter coming from fossil fuel can cause atherosclerosis, thrombosis (Nemmar et al 2006), affects blood pressure(Simkhovich et al 2008) and increases risk of coronary events(Bareegard et al 2006). It may be concluded that wood smoke has an ill effect on health by raising the blood cholesterol level.

\section{Blood Triglycerides}

Blood triglyceride level in workers was high $(125 \pm 10 \mathrm{mg} / \mathrm{dl})$ as compared to control $(97 \pm$ $1.5 \mathrm{mg} / \mathrm{dl}$ ) (Table 2). The smoking raises triglyceride level (American Heart Association 1983)and raises the Low Density Lipid (Mikhailidi 1998).

\section{Serum Glutamate Pyruvate Transaminase (SGPT)}

SGPT level of workers and control was $68 \pm 2.4 \mathrm{IU} / \mathrm{L}$ and $28 \pm 1.1 \mathrm{IU} / \mathrm{L}$ (Table 2). Workers have high SGPT level. The serum alanine aminotransferase (ALT) about 1.5 fold the normal limit is caused by the inhalation of smoke having high concentration of Hydrocarbons and Chlorinated vapors (Loh et al 2006). Among HCV seropositive subjects smoking and alcohol consumption significantly elevated ALT level (Wang et al 2002).

\section{Blood Glucose}

There was a significant increase in blood glucose level of workers $(113 \pm 2.1 \mathrm{mg} / \mathrm{dl})$ as compared to control group $(101 \pm 1.2 \mathrm{mg} / \mathrm{dl}$ ) (Table 2). Same results have also been given byBornemisza and Suciu 1980 after smoke inhalation and blood glucose level raised as compared to control group.

\section{Blood profile}

\section{Total Red Blood Cells (TRBC) count}

The TRBC in workers was $5.6 \pm 0.035 \mathrm{mil} / \mathrm{cmm}$ and in control was $4.3 \pm 0.027 \mathrm{mil} / \mathrm{cmm}$ (Table 2). Workers have high TRBC than control. Smoking at high altitude further increases RBC count(Ramirez et al 1991). Roethig et al2010stated that by stopping smoke cigarette, a significant decrease up to $9 \%$ in RBC is reported within three days. It has been concluded that wood smoke increases total red blood cell count.

\section{Hemoglobin}

The hemoglobin level in workers was $15 \pm 0.054 \mathrm{mg} / \mathrm{dl}$ and in control was $12 \pm 0.064 \mathrm{mg} / \mathrm{dl}$ (Table 2). The smoking increases the hemoglobinlevel both in men and women (Nordenberg et al1990 andBinkin et al 1993).

\section{Hematocrit Value}

The Hematocrit level in workers was $49 \pm 0.22 \mathrm{mg} / \mathrm{dl}$ while in control was $38 \pm 0.11 \mathrm{mg} / \mathrm{dl}$ (Table 2). 


\section{Macrothink}

The present study is also in correlation with Goldbourt and Medalie1977, who determined that current smokers have high hematocrit level than non smokers.

\section{Mean corpuscular Volume}

The MCV in workers was $86 \pm 0.22 \mathrm{fl}$ and in control was $75 \pm 0.30 \mathrm{fl}$ (Table 2). Same results have been reported by Kondo et al1993.

\section{Mean Corpuscular Hemoglobin}

The MCH for workers was $31 \pm 0.12 \mathrm{pg}$ and for control, was $25 \pm 0.37 \mathrm{pg}$ (Table 2). The results are in agreement with Kondo et al1993, who found that in smokers MCH level is high. It has beenconcluded that $\mathrm{MCH}$ level is raised when compared to control.

\section{Mean Corpuscular Hemoglobin Concentration}

The MCHC was high in workers $(35 \pm 0.12 \mathrm{gm} / \mathrm{dl})$ as compared to control $(31 \pm 0.11 \mathrm{gm} / \mathrm{dl})($ Table 2). Similar resulthas also been reported by Kondo et al1993, who found that individual chronically exposed to smoke has higher level of MCHC.

\section{Neutrophil}

In control, neutrophils count was $56 \pm 0.82 \%$, while in workers it was $77 \pm 0.50 \%$ (Table 2).Human exposure to diesel particles for 1 hour at 300 microgram/cubic meter resulted in increased level of peripheral neutrophils(Schwartz 2001).

\section{Eosinophils}

For workers, the mean value of eosinophil was $6.0 \pm 0.14 \%$ and for control was $3.1 \pm 0.20 \%$ (Table 2).Lal et al1993obtained similar results by exposing rats to wood smoke for 30 and 45 days and found increased number of esosinophils in the blood.

\section{Lymphocytes}

There was a significant increase in lymphocyte count of workers $(45 \pm 1.0 \%)$ as compared to control (34 $\pm 1.0 \%$ )(Table 2).Lymphocyte percentage is associated with smoking and is therefore higher in smokers (Huang et al 2001 and Rutgerz et al 2000).

\section{Monocytes}

The mean count of monocyte for workers was $7.7 \pm 0.19 \%$ while for control was $4.2 \pm 0.12 \%$ (Table 2). Present results are in agreement with the finding of Adams et al1997and Huang et al2001. They found that smoke increases monocyte count. Ray et al2006found that biomass smoke exposure causes activation of monocyte.

\section{Total Leukocytes Count}

The TLC was high in workers $(11014 \pm 115 / \mathrm{cmm})$ as compared to control $(6573 \pm 125 / \mathrm{cmm})($ Table 2).Thesmoke exposure increase white blood cells count (Yanbaeva et al 2007 and Megan 2003). Kondo et al1993studied the relationship of cigarette smoke and hematological parameters and analyzed that smoking increases TLC. 


\section{Platelets}

The mean value of platelets for workers was $235864 \pm 5491 / \mathrm{cmm}$ and for control were $169162 \pm$ $2454 / \mathrm{cmm}$ (Table 2).Milton and Cuyler1956, Reed et al2006, Ray et al2006and Sithu et al2010havestated same results.

Table 2. Comparative analysis of the blood biochemical parameters of the control and Tandoor occupants.

\begin{tabular}{|l|c|c|c|c|}
\hline \multirow{2}{*}{ Parameters } & Control & Workers & \multirow{2}{*}{ 95\% C.I } & \multirow{2}{*}{ P value } \\
\cline { 2 - 3 } & Mean \pm SD & Mean \pm SD & & \\
\hline Glucose & $101 \pm 1.2$ & $113 \pm 2.1$ & -16 to -6.7 & $<0.0001$ \\
\hline Lymphocytes & $34 \pm 1.0$ & $45 \pm 1.0$ & -14 to -8.5 & $<0.0001$ \\
\hline Platelets & $169162 \pm 2454$ & $235864 \pm 5491$ & 54749 to 78654 & $<0.0001$ \\
\hline SGPT & $28 \pm 1.1$ & $68 \pm 2.4$ & -45 to -34 & $<0.0001$ \\
\hline Hb\% & $12 \pm 0.064$ & $15 \pm 0.054$ & 2.8 to 3.1 & $<0.0001$ \\
\hline HCT & $38 \pm 0.11$ & $49 \pm 0.22$ & 10 to 11 & $<0.0001$ \\
\hline Cholesterol & $111 \pm 2.4$ & $131 \pm 4.8$ & -31 to -9.3 & .0003 \\
\hline MCH & $25 \pm 0.37$ & $31 \pm 0.12$ & 5.5 to 7.1 & $<0.0001$ \\
\hline MCHC & $31 \pm 0.11$ & $35 \pm 0.12$ & 3.2 to 3.8 & $<0.0001$ \\
\hline MCV & $75 \pm 0.30$ & $86 \pm 0.22$ & 10 to 12 & $<0.0001$ \\
\hline Neutrophil & $56 \pm 0.82$ & $77 \pm 0.50$ & -23 to -19 & $<0.0001$ \\
\hline Eusinophils & $3.1 \pm 0.20$ & $6.0 \pm 0.14$ & -3.4 to -2.4 & $<0.0001$ \\
\hline Monocytes & $4.2 \pm 0.12$ & $7.7 \pm 0.19$ & -3.9 to -3.0 & $<0.0001$ \\
\hline TG & $97 \pm 1.5$ & $125 \pm 10$ & -48 to -8.0 & 0.0066 \\
\hline TLC & $6573 \pm 125$ & $11014 \pm 115$ & -4778 to -4104 & $<0.0001$ \\
\hline TRBC & $4.3 \pm 0.027$ & $5.6 \pm 0.035$ & 1.2 to 1.4 & $<0.0001$ \\
\hline
\end{tabular}

$\mathrm{SD}=$ Standard Deviation, C.I $=$ Confidence Interval

\section{Conclusion}

From the present study, it is concluded that wood smoke has harmful effects on the persistently exposed people. In workers, wood smoke exposure leads to hypertension, lungs infection, dry cough, chest pain and physical weakness. In adults such problems were more severe as compared to young ones. It has been concluded that workers are at more risk to heart and liver diseases because the biochemical parameters such as SGPT, blood cholesterol, blood triglyceride and blood glucose level were found high as compared to control group. Such workers are also at more risk of getting lungs infections/abnormalities as compared to control group.

\section{Recommendations}

To check the effects of chronic exposure to wood smoke and its toxicants; a study on large population should be performed, and a work on female Tandoor occupants will also be necessary in the same locality. The printed as well as electronic media should aware the people from the hazardous effects of wood smoke generating during cooking and baking process. 


\section{Limitations}

In present study, a small number of population sizeand only the male individuals were considered. The toxicants inindoor environment of work place were not measured due to unavailability of facilities.Toxicants were not measured in blood, it is recommended to check the toxicants in indoor environment as well as in blood to co-relate the results and to boost the validity of the results.

\section{References}

Adams, M. R., Jessup, W.,\&Celermajer.(1997). Cigarette smoking is associated with increased human Monocyte adhesion to endothelial cells. Journal of American College of Cardiology, 491-497. http://dx.doi.org/10.1016/S0735-1097(96)00537-2

American Heart Association, Triglyceride, (1983). www.americanheart.orq

Barregard, L., Sallste, G., Andersson, L., Almstmansd, A. C., Gustafson, P., Andersson, M., \& Olin, A. C. (2006). Experimental exposure to wood-smoke particles in healthy humans: Effects on markers of inflammation - coagulation and lipid peroxidation. Inhalation Toxicology, 845-53. http://dx.doi.org/10.1080/08958370600685798

Binkin.,Nancy, J., Nordenberg., Dale., Yip., \& Ray. (1993). The effect of cigarette smoking on hemoglobin level and anemia screening. Journal of American Medical Association, 1556-9.

Bornemisza, P., \& Suciu, I. (1980). Effect of cigarette smoking on the blood glucose level in normal and diabetics.Medicine Interne, 353-6.

Colbeck, I., Nasir, Z. A., \& Ali, Z. (2010). The state of indoor air quality in Pakistan- a review.Environmental Science and Pollution Research International, 17(6), 1187-96. http://dx.doi.org/10.1007/s11356-010-0293-3

Franchini, M., \& Mannucci, P. M. (2011). Thrombogenecity and cardiovascular effects of ambient air pollution. Journal of the American College of Cardiology, 52(9), 719-26.

Fullerton, D. G., Suseno, A., Semple, S., Kalambo, F., Malambo, R., White, S., Jack, S., Calverly, P. M., \& Gordon, S. B. (2011). Wood smoke exposure, poverty and impaired lung function in Malawian adults. International Journal of Tuberculosis and Lung Diseases, 15(3), 391-8.

Goldbourt, U., \& Jack, H. M. (1977). Characteristics of smokers, non- smokers and ex- smokers among 10,000 adult males in Israel. American Journal of Epidemiology, 75-86.

Huang, Z. S., Chien, K. L., Yang, C. Y., Tsai, K. S., \& Wang, C. H. (2001). Peripheral differential leukocyte counts in humans vary with hyperlipidemia, smoking, and body mass index. Lipids, 237-45. http://dx.doi.org/10.1007/s11745-001-0713-9

Kondo, H., Kusaka, Y., \& Morimoto, K. (1993). The effects of life style on hematological parameters: Analysis of hematological data in association with smoking habit and age. SangyoIgaku, 98-104. http://dx.doi.org/10.1539/joh1959.35.98

Lal, K., Dutta. K. K., Vachhrajani, K. D., Gupta, G. S., \& Srivastava, A. K. (1993). Histomorphological changes in lung of rats following exposure to wood smoke. Indian Journal of 
Experimental Biology, 761-4.

Loh, C. H., Chang, Y. W., Lious, S. H., Chang, J. H., \& Chen, I. (2006). Case report: Hexa chloroethane smoke inhalation: A rare cause of hepatic injuries. Enviromental Health Perspectives, 763-5. http://dx.doi.org/10.1289/ehp.8635

Mccraken, J. P., Smith, K. R., Mittleman, M. A., \& Schwartz, J. (2010). Chimney stove intervention to reduce long term wood smoke exposure lowers blood pressure among Guatemalan women. Environmental Health Perspectives, 115(7), 996-1001. http://dx.doi.org/10.1289/ehp.9888

Megan, R., \& Smith. (2003). Smoking status and differential white cell count in men and women in the EPIC- Norfolk population.Atherosclerosis, 331-337.

Mikhailidis, D. P. (1998). Smoking, Diabetes and Hyperlipidaemia. Journal of the Royal Society of Health, 91-3. http://dx.doi.org/10.1177/146642409811800209

Milton, E. E., \& Cuyler, H. (1956). The effects of smoking on packed cell volume, RBC and platelets count. Cannadian Medical Association Journal, 520-53.

Minnesota Pollution Control Agency. (2012). Health Effects of Wood Smoke; Home, Air, Air Quality and Pollutants, General Air Quality, Wood Smoke.http://www.Pca.state.mn.us/indexphp/air/aiqualityandpollutants/generalairquality/woodsm oke/healtheffectswoodmokhtml. accessed onOctober, 2012.

Nemmar, A., Hoylaerts, M. F., \& Nemery, B. (2006). Effects of particulate air pollution on hemostasis.Clinics in Occupational and Enviromental Medicine, 865-81.

Nordenberg, D., Ray, Y., \& Nancy, J. B. (1990). The effects of cigrate smoking on hemoglobin and anemia screening. Journal of American Medical Association, 1556-1559. http://dx.doi.org/10.1001/jama.1990.03450120068031

Perez, P. R., Schil, M. A., \& Riojas, R. H. (2010). Respiratory health effects of indoor air pollution. International Journal of Tuberculosis and Lung Diseases, 14(9), 1079-86.

Ramirez, G., Bittle, P. A., Colice, G. L., Herrera, R., Agosti, S. J., \& Foulis, P. R. (1991). The effects of cigarette smoking upon hematological adaptation to moderately high altitude living. Wilderness Medicine, 274-286. http://dx.doi.org/10.1580/0953-9859-2.4.274

Ray, M. R., Mukherjee, S., Roychoudhury, S., Bhattacharya, P., Banerjee, M., Siddique, S., Chakraborty, S., \& Lahiri,T. (2006). Platelet activation, upregulation of CD11b/CD18 expression on leukocytes and increase in circulating leukocyte-platelet aggregates in Indian women chronically exposed to biomass smoke. Human and Experimental Toxicology, 25(11), 627-35. http://dx.doi.org/10.1177/0960327106074603

Reed, M. D., Campen, M. J., Gigliotti, A. P., Harrod, K. S., McDonald, J. D.,Seagrave, J. C., Mauderly, J. L., \& Seilkop, S. K. (2006). Health effects of subchronic exposure to environmental levels of hardwood smoke.Inhalation Toxicology, 523-39. http://dx.doi.org/10.1080/08958370600685707

Riddervold, I. S., Bonlokke, J. H., Molhave, L., Massling, A., Jenson, B., Gronborg, T. K., Bossi, R., 


\section{I Macrothink}

Forchhammer, L., Kiargaard, S. K., \&Sigsgaard, T. (2011). Wood smoke in a controlled exposure experiment with human volunteers.Inhalation Toxicology, 23(5), 277-88. http://dx.doi.org/10.3109/08958378.2011.567401

Roethig, H. J., Koval, T., Muhammad, K. R., Jin, Y., Mendes, P., \& Unverdorben, M. (2010). Short term effects of reduced exposure to cigarette smoke on White Blood Cells, Platelates and Red Blood Cells in adult cigarette smokers. Regulatory Toxicology and Pharmacology, 333-7. http://dx.doi.org/10.1016/j.yrtph.2010.04.005

Rutgers, S. R., Postma, D. S., Ten, N. H., Kauffman, H. F., Vander, M. T. W., Koeter, G. H., \& Timens, W. (2000). Ongoing air way inflammation in patient with Chronic Obstructive Pulmonary Disease (COPD) who do not currently smoke.Thorax, 12-8. http://dx.doi.org/10.1136/thorax.55.1.12

Schwartz, J. (2001). Air pollution and blood markers of cardiovascular risk.Enviromental Health Perspectives, 405-409.

Simkhovich, B. Z., Kleinman, M. T., \& Kloner, R. A. (2008). Air pollution and cardiovascular injury epidemiology, toxicology and mechanisms.Journal of the American College of Cardiology, 719-26. http://dx.doi.org/10.1136/thorax.55.1.12

Sithu, S. D., Srivastava, S., Siddiqui, M. A., Vladykovskaya, E., Riggs, D. W., Conklin, D. J., Haberzettl, P., O'Toole, T. E., Bhatnagar, A., \& D'Souza, S. E. (2010). Exposure to acrolein by inhalation causes platelet activation. Toxicology and Applied Pharmacology, 100-10. http://dx.doi.org/10.1016/j.taap.2010.07.013

Steven, R. (2011). A Tandoori Oven brings India's heat to the backyard. New York Times, Wikipedia, Accessed on 2nd December, 2012.

Wang, C. S., Wang, S. T., Chang, T. T., Yao, W. J., \& Chou, P. (2002). Smoking and alanine aminotransfease level in hepatitis c virus infection: implifications for prevention of hepatitis c virus progression. Archives of International 811-5. http://dx.doi.org/10.1001/archinte.162.7.811

Yanbaeva, D. G., Dentener, M. A., Creutzberg, E. C., Wesseling, G., \& Wouters, E. F. (2007). Systemic effect of smoking. Chest, 1557-66. http://dx.doi.org/10.1378/chest.06-2179

\section{Copyright Disclaimer}

Copyright reserved by the author(s).

This article is an open-access article distributed under the terms and conditions of the Creative Commons Attribution license (http://creativecommons.org/licenses/by/3.0/). 